\title{
PENGARUH MODEL PEMBELAJARAN PEROLEHAN KONSEP BERBASIS MASALAH TERHADAP KEMAMPUAN PEMECAHAN MASALAH DAN PEMAHAMAN KONSEP FISIKA PESERTA DIDIK KELAS XI MIA MAN 1 MATARAM
}

\author{
Hidayatul Aini ${ }^{1)}$, Sutrio ${ }^{1)}$, Aris Doyan ${ }^{1)}$ \\ ${ }^{1)}$ Program Studi Pendidikan Fisika, FPMIPA, Universitas Mataram, Mataram, Indonesia \\ Corresponding author : Hidayatul Aini \\ E-mail : hidayathidayah9@gmail.com
}

Diterima 6 Januari 2020, Disetujui 2 April 2020

\begin{abstract}
ABSTRAK
Penelitian ini bertujuan untuk mengetahui pengaruh model pembelajaran perolehan konsep berbasis masalah terhadap kemampuan pemecahan masalah dan pemahaman konsep fisika peserta didik kelas XI MIA MAN 1 Mataram. Penelitian ini merupakan penelitian quasi experiment dengan desain penelitian non-equivalent control group design. Subjek dari penelitian ini adalah peserta didik kelas XI MIA 1 sebanyak 37 peserta didik sebagai kelas eksperimen dan kelas XI MIA 2 sebanyak 38 peserta didik sebagai kelas kontrol. Kelas eksperimen diberi perlakuan berupa model pembelajaran perolehan konsep berbasis masalah sedangkan kelas kontrol diberi perlakuan berupa pembelajaran konvensional. Tes uraian digunakan untuk mengukur kemampuan pemecahan masalah fisika peserta didik berjumlah 5 butir soal dan tes pilihan ganda untuk mengukur pemahaman konsep fisika peserta didik sebanyak 10 butir soal yang sudah diuji validitas, reliabilitas, daya pembeda dan tingkat kesukarannya. Hipotesis penelitian diuji menggunakan uji MANOVA. Hasil uji hipotesis menunjukkan nilai signifikansi sebesar 0,00 . Taraf signifikan yang digunakan ialah 0,05 maka dapat dikatakan $0,00<0,05$ yang artinya bahwa $\mathrm{H}_{0}$ ditolak dan Ha diterima, sehingga dapat disimpulkan bahwa terdapat pengaruh model pembelajaran perolehan konsep berbasis masalah terhadap kemampuan pemecahan masalah dan pemahaman konsep fisika peserta didik kelas XI MIA MAN1 Mataram.
\end{abstract}

Kata kunci: model pembelajaran perolehan konsep berbasis masalah; kemampuan pemecahan masalah; pemahaman konsep.

\begin{abstract}
This study aims to determine the effect of the learning model of problem-based concept acquisition on problem solving abilities and understanding of physics concepts of students of class XI MIA MAN 1 Mataram. This research is a quasi-experimental with a non-equivalent control group design. The subjects of this study were $37 \mathrm{XI}$ MIA 1 students as experimental class and 38 MIA 2 XI students as control class. The experimental class given treatment problem-based concept learning model while the control class given treatment conventional learning. Description test is used to measure the students 'physical problem-solving abilities totaling 5 items and multiple choice tests to measure students' understanding of physics concepts by 10 items that have been tested for validity, reliability, distinguishing power and degree of difficulty. The research hypothesis was tested using the MANOVA test. The results of the hypothesis test showed a significance value of 0.00 . Significant level used is 0.05 , it can be said to be $0.00<0.05$, which means that $\mathrm{H}_{0}$ is rejected and $\mathrm{Ha}$ accepted, so can be concluded that there are significant acquisition of concept-based learning model on problem solving skills and understanding of physics concepts of students of class XI MIA MAN 1 Mataram.
\end{abstract}

Keywords: concept attainment learning model of problem based; problem solving abilities; understanding concept

\section{PENDAHULUAN}

Fisika merupakan cabang dari IImu Pengetahuan Alam (IPA) yang berkaitan dengan produk dan proses. Pembelajaran fisika juga membahas mengenai konsep-konsep dan hukum fisika (Hastuti et. al., 2016:129). Oleh karena itu, pembelajaan fisika perlu dilakukan kegiatan eksperimen agar konsep-konsep dan hukum fisika tersebut dapat tersampaikan. Selain itu guru dalam hal ini dituntut memiliki kemampuan untuk memilih model pembelajaran yang tepat dan bervariasi 
sehingga tujuan dalam pembelajaran fisika dapat sesuai dengan yang tertuang dalam kurikulum 2013.

Kementrian pendidikan dan kebudayaan dalam kurikulum 2013 menyebutkan tujuan dari pembelajaran fisika yaitu peserta didik mampu menguasai konsepkonsep fisika dan menggunakan metode ilmiah yang dilandasi sikap ilmiah untuk memecahkan masalah-masalah yang dihadapi dalam kehidupan sehari-hari.

Pembelajaran fisika di sekolah saat ini masih belum sesuai dengan yang diharapkan. Hasil wawancara yang telah dilakukan oleh peneliti kepada salah satu guru mata pelajaran fisika di MAN 1 Mataram memaparkan bahwa pembelajaran fisika di MAN 1 Mataram masih menggunakan model pembelajaran konvensional. Peserta didik cenderung hanya mendengarkan dan mencatat informasi yang disampaikan guru, selain itu kegiatan eksperimen jarang dilakukan karena banyaknya materi tidak sesuai dengan jam pelajaran yang mengakibatkan kurangnya pemahaman konsep fisika dan kemampuan peserta didik dalam menjawab permasalahan yang disajikan, sehingga berdampak pada nilai mata pelajaran fisika yang masih di bawah KKM.

Cara yang dapat digunakan untuk mencapai tujuan pembelajaran fisika sesuai kurikulum 2013 yaitu menggunakan model pembelajaran. Model pembelajaran memiliki ciri-ciri yaitu berdasarkan teori pendidikan dan teori belajar dari para ahli tertentu, mempunyai misi atau tujuan pendidikan tertentu, dapat dijadikan pedoman untuk perbaikan kegiatan belajar mengajar dikelas, memiliki bagianbagian model yang dinamakan: (a) urutan langkah-langkah pembelajaran; (b) adanya prinsip-prinsip reaksi; (c) sistem sosial; dan (d) sistem pendukung, memiliki dampak sebagai akibat terapan model pembelajaran, dan membuat persiapan mengajar (desain instruksional) dengan pedoman model pembelajaran yang dipilih (Listiawati et. al., 2015:48).

Salah satu model pembelajaran yang diharapkan dapat mencapai tujuan pembelajaran fisika yaitu model pembelajaran perolehan konsep. Model pembelajaran perolehan konsep merupakan model pengajaran yang dirancang untuk membantu peserta didik dari semua usia mengambangkan dan menguatkan pemahaman mereka tentang konsep dan mempraktikkan berpikir kritis dalam pembelajaran (Eggen \& Kauchak, 2016:2018). Penelitian sebelumnya yang terkait dengan model perolehan konsep seperti yang dilakukan oleh Sahara (2015:70) menyatakan bahwa model perolehan konsep lebih efektif dalam menanamkan dan pembentukan konsep peserta didik, dapat mengkonstruksi sendiri pengetahuannya, menyebutkan ciri-ciri penting suatu konsep untuk membedakan dengan konsep lain yang sejenis.

$$
\text { Risdawati et. al., (2017:162) }
$$
memaparkan bahwa model pembelajaran perolehan konsep adalah proses mengidentifikasi dan mendefinisikan konsep dengan jalan menemukan atributnya yang paling esensial sesuai dengan pengertian konsep yang dipelajari. Lebih lanjut Fadilah dan Suyono (2016:465) mengatakan atribut tersebut harus membedakan contoh konsep itu dengan yang bukan contoh konsep. Penerapan dari model pembelajaran ini sangat berguna untuk membantu peserta didik dalam mengatasi tantangan pada gaya belajarnya yang berbedabeda. Adapun kelebihan yang terdapat didalam model pembelajaran perolehan konsep yaitu meningkatkan kemampuan awal untuk belajar lebih mudah dan lebih efektif. Sa'diyah dkk (2015:226) mengatakan implementasi model perolehan konsep dapat dijadikan salah satu cara agar peserta didk dapat menjadi aktif dan termotivasi untuk belajar sehingga tujuan pembelajaran dapat tercapai dengan baik.

Model perolehan konsep dalam pembelajaran fisika yang diterapkan dikelas selama ini sebatas menyajikan beberapa contoh konsep dan bukan konsep yang berkaitan dengan materi yang diajarkan. Beberapa penelitian yang terkait diantaranya penelitian yang dilakukan oleh Legat dalam jurnal Riset Fisika Edukasi Sains (2018:11) yang menerapkan pembelajaran perolehan konsep dengan cara melakukan analisis terhadap contoh yang diberikan oleh guru yang berhubungan dengan konsep yang dipelajari. Guru mengawali pengajaran dengan menyajikan data yang terkait dengan materi pembelajaran, kemudian meminta peserta didik untuk mengamati ciri-ciri data tersebut dan menjelaskan definisi konsep berdasarkan ciriciri data. Penelitian yang terkait juga dilakukan oleh Rahmi dkk dalam jurnal Inovasi Pembelajaran Fisika (2013:187) yang menerapkan model perolehan konsep dengan mencari dan mendaftar sifat-sifat yang dapat digunakan untuk membedakan contoh-contoh konsep dengan bukan contoh konsep terkait dengan materi yang diajarkan. Sehingga peneliti tertarik untuk memadukan pembelajaran perolehan konsep dengan pembelajaran berbasis masalah.

Herayanti dan Habibi (2015:62) memaparkan bahwa pembelajaran berbasis masalah adalah sutau model pembelajaran yang menggunakan masalah sebagai titik tolak pembelajaran. Masalah tersebut adalah 
masalah yang memenuhi konteks dunia nyata baik yang ada di dalam buku teks maupun dari sumber lain seperti peristiwa yang terjadi di lingkungan sekitar, keluarga dan kemasyarakatan. Lebih lanjut Nurdyansyah dan Fahyuni (2016:93) mengatakan bahwa dalam pembelajaran berbasis masalah peserta didik merumuskan dan menganalisis masalah dengan mengidentifikasi fakta-fakta yang relevan, menghasilkan hipotesis yang telah dirumuskan. Dalam pembelajaran berbasis masalah terjadi empat tahapan diantaranya: (1) tahap pemberian masalah dengan peserta didik diberikan fenomena; (2) pada tahap ke dua yaitu tahap menuliskan apa yang diketahui untuk kemudian peserta didik melakukan serangkaian kegiatan ilmiah; (3) pada tahap ke tiga yaitu tahap menuliskan inti permasalahan; (4) pada tahap ke empat yaitu tahap menuliskan cara pemecahan masalah dan merumuskan beberapa alternatif pemecahan masalahnya (Rusnayati dan Prima, 2011:332). Sehingga Pembelajaran perolehan konsep yang dipadukan dengan pembelajaran berbasis masalah diharapkan dapat lebih mendorong peserta didik untuk ikut aktif dalam pembelajaran karena disamping mengetahui dan memahami konsep, peserta didik juga dapat melakukan serangkaian kegiatan ilmiah yang dapat memberikan peserta didik kesempatan dalam menemukan dan mengembangkan sendiri pengetahuannya.

Menurut (Maulidi et al., 2014:109) pemecahan masalah tidak hanya merupakan kemampuan menerapkan konsep terdahulu namun juga suatu proses untuk menemukan konsep yang baru. Kemampuan pemecahan masalah memerlukan suatu keterampilan dan kemampuan khusus yang dimiliki masingmasing peserta didik, yang mungkin akan berbeda antar peserta didik dalam menyelesaikan suatu masalah.

Pemahaman merupakan hasil belajar mengajar yang mempunyai indikator dan setiap individu dapat menjelaskan atau mendefenisikan suatu bagian informasi dengan kata-kata sendiri (Riana et. al., 2019:65). Kemampuan memahami juga dapat diartikan sebagai kemampuan mengerti tentang hubungan antarfaktor, antarkonsep, antarprinsip, antardata, hubungan sebab akibat, dan penarikan kesimpulan. Kemampuan memahami dalam kegiatan belajar ditunjukkan melalui: (1) mengungkapkan gagasan, atau pendapat dengan kata- kata sendiri, (2) membedakan, membandingkan, menginterpretasi data, mendeskripsikan dengan kata-kata sendiri, (3) menjelaskan gagasan pokok, dan (4) menceritakan kembali dengan kata-kata sendiri (Kunandar, 2013:162163).

\section{METODE PENELITIAN}

Jenis penelitian ini adalah penelitian kuasi eksperimen (non-equivalen grup design). Pada kuasi eksperimen dalam kaitannya dengan pemilihan subjek penelitian, peneliti tidak selalu dapat melakukan pemilihan subjek secara random (Setyosari, 2013). Adapun teknik pengambilan sampel yang peneliti gunakan dalam penelitian ini ialah purposive sampling, yaitu teknik yang digunakan peneliti jika peneliti mempunyai pertimbanganpertimbangan tertentu dalam pengambilan sampel (Riduwan, 2018:20). Sampel penelitian yaitu peserta didik MAN 1 Mataram Kelas XI MIA 1 sebanyak 37 peserta didik sebagai kelas eksperimen dan kelas XI MIA 2 sebanyak 38 peserta didik sebagai kelas kontrol. Instrumen yang digunakan pada penelitian ini yaitu instrumen tes kemampuan pemecahan masalah berupa soal uraian dan instrumen tes pemahaman konsep berupa soal pilihan ganda. Teknik pengumpulan data menggunakan metode tes.

\section{HASIL DAN PEMBAHASAN}

Data yang diperoleh dari penelitian ini meliputi data kemampuan pemecahan masalah dan pemahaman konsep fisika peserta didik sebelum dan sesudah diberiaknnya perlakuan.

\section{A. Data Kemampuan Pemecahan Masalah dan Pemahaman Konsep}

Tabel 1. Nilai rata-rata Kemampuan Pemecahan Masalah dan Pemahaman Konsep Fisika Peserta Didik

\begin{tabular}{|c|c|c|c|c|c|}
\hline Kelas & $\begin{array}{l}\text { Kem } \\
\text { ampu } \\
\text { an }\end{array}$ & $\begin{array}{l}\text { Rat } \\
\text { a- } \\
\text { rata } \\
\text { pret } \\
\text { est }\end{array}$ & $\begin{array}{l}\text { Kate } \\
\text { gori }\end{array}$ & $\begin{array}{l}\text { Rata } \\
\text {-rata } \\
\text { postt } \\
\text { est }\end{array}$ & $\begin{array}{l}\text { Kate } \\
\text { gori }\end{array}$ \\
\hline \multirow{2}{*}{$\begin{array}{l}\text { Ekspe } \\
\text { rimen }\end{array}$} & KPM & $\begin{array}{l}44 \\
28\end{array}$ & $\begin{array}{l}\text { Rend } \\
\text { ah }\end{array}$ & $\begin{array}{l}53,7 \\
3\end{array}$ & $\begin{array}{l}\text { Rend } \\
\text { ah }\end{array}$ \\
\hline & PK & $\begin{array}{l}48,3 \\
7\end{array}$ & $\begin{array}{l}\text { Rend } \\
\text { ah }\end{array}$ & $\begin{array}{l}60,5 \\
4\end{array}$ & $\begin{array}{l}\text { Seda } \\
\text { ng }\end{array}$ \\
\hline \multirow{2}{*}{$\begin{array}{l}\text { Kontro } \\
\text { I }\end{array}$} & KPM & $\begin{array}{l}31,7 \\
1\end{array}$ & $\begin{array}{l}\text { Rend } \\
\text { ah }\end{array}$ & $\begin{array}{l}42,5 \\
8\end{array}$ & $\begin{array}{l}\text { Rend } \\
\text { ah }\end{array}$ \\
\hline & PK & $\begin{array}{l}48,1 \\
5 \\
\end{array}$ & $\begin{array}{l}\text { Rend } \\
\text { ah }\end{array}$ & $\begin{array}{l}56,3 \\
1 \\
\end{array}$ & $\begin{array}{l}\text { Seda } \\
\text { ng }\end{array}$ \\
\hline
\end{tabular}

Keterangan :

$\mathrm{KPM}=$ Kemampuan pemecahan masalah

$\mathrm{PK}=$ Pemahaman konsep 


\section{B. Data Kemampuan Pemecahan Masalah Setiap Indikator}

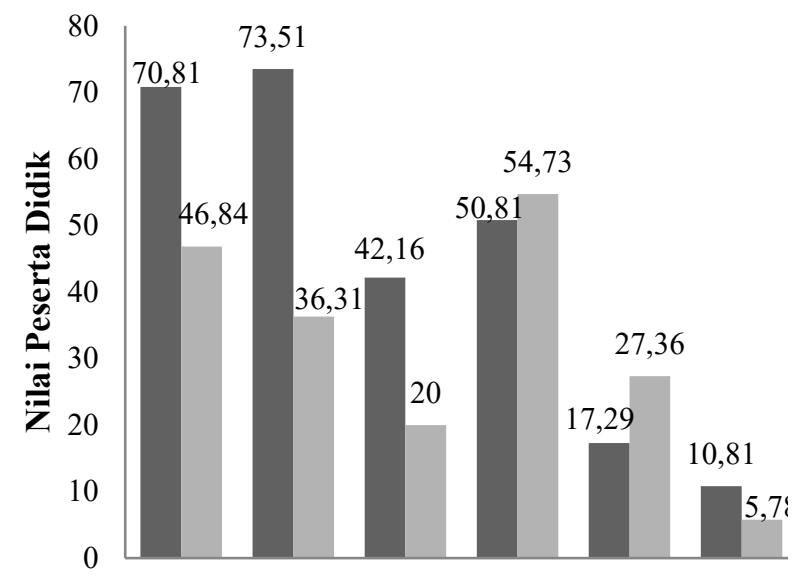

IPM-1 IPM-2 IPM-3 IPM-4 IPM-5 IPM-6

- Kelas Eksperimen Kelas Kontrol

Gambar 1. Nilai Rata-rata Pretest Kemampuan

Pemecahan Masalah Fisika Peserta Didik Setiap Indikator yaitu IPM-1 (pemahaman), IPM-2 (pemilihan), IPM-3 (pembedaan), IPM-4 (penentuan), IPM-5 (penerapan), dan IPM-6 (pengidentifikasian)

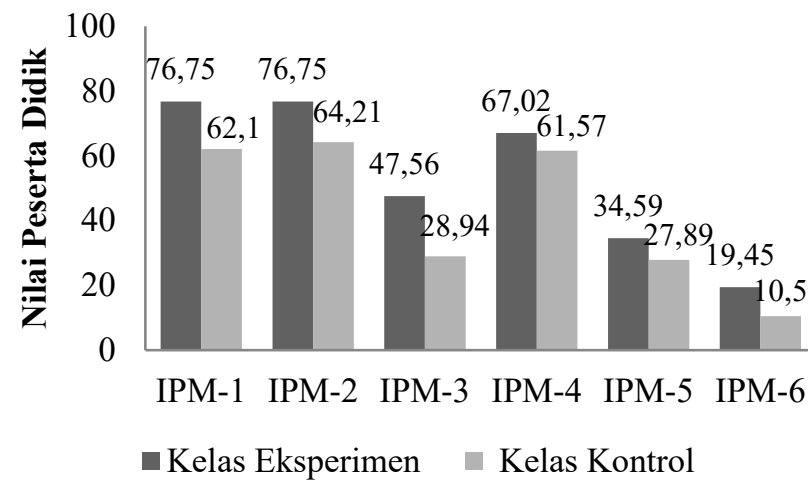

Gambar 2 Nilai Rata-rata Pretest Kemampuan Pemecahan Masalah Fisika Peserta Didik Setiap Indikator yaitu IPM-1 (pemahaman), IPM-2 (pemilihan), IPM-3 (pembedaan), IPM-4 (penentuan), IPM-5 (penerapan), dan IPM-6 (pengidentifikasian).

\section{Data Pemahaman Konsep Setiap Indikator}

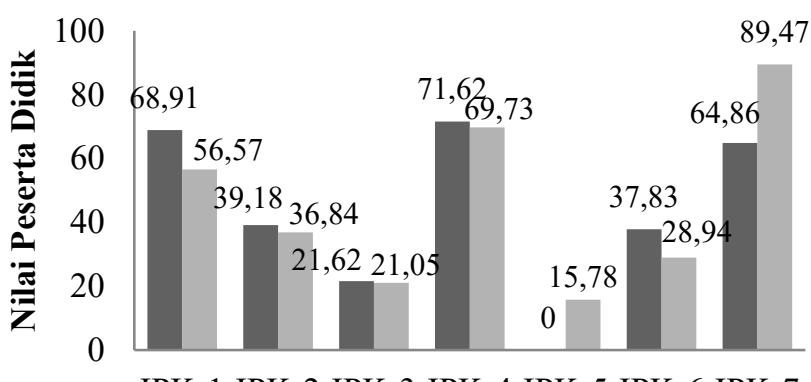

IPK-1 IPK-2 IPK-3 IPK-4 IPK-5 IPK-6 IPK-7

- Kelas Eksperimen $\square$ Kelas Kontrol

Gambar 3. Nilai Rata-rata Pretest

Pemahaman Konsep Fisika Peserta Didik

Setiap Indikator yaitu IPK-1 (menafsirkan), IPK-2 ( mencontohkan), IPK-3

(mengklasifikasikan), IPK-4 (merangkum), IPK-5 (menyimpulkan), IPK-6 (membandingkan), dan IPK-7 (menjelaskan).

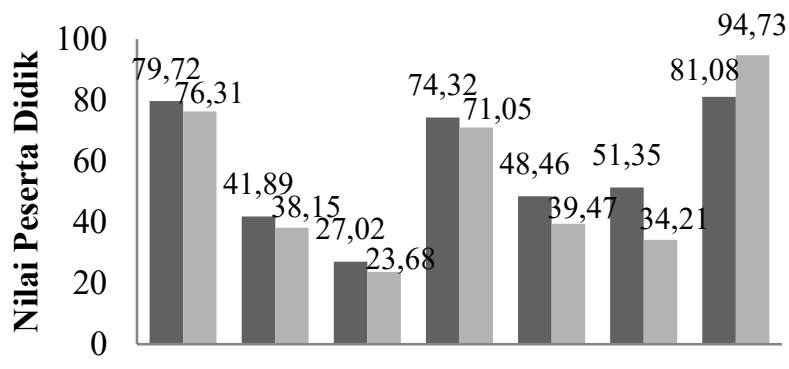

IPK-1 IPK-2 IPK-3 IPK-4 IPK-5 IPK-6 IPK-7

Kelas Eksperimen Kelas Kontrol

Gambar 4 Nilai Rata-rata Posttest

Pemahaman Konsep Fisika Peserta Didik

Setiap Indikator yaitu IPK-1 (menafsirkan),

IPK-2 ( mencontohkan), IPK-3

(mengklasifikasikan), IPK-4 (merangkum), IPK5 (menyimpulkan), IPK-6 (membandingkan), dan IPK-7 (menjelaskan)

Ditinjau dari setiap indikator yang diukur, untuk indikator kemampuan pemecahan masalah yang paling dikuasai peserta didik baik kelas eksperimen maupun kelas kontrol ialah pemilihan. Indikator pemilihan ini merupakan kemampuan yang dimiliki peserta didik untuk dapat memilih penyebab-penyebab yang berkaitan dengan soal atau fenomena fisika. Tingginya kemampuan peserta didik pada indikator pemilihan karena peserta didik kelas eksperimen disajikan permasalahan dalam bentuk fenomena fisika yang berkaitan dengan materi yang diajarkan yaitu materi elastisitas dan hukum Hooke yang harus mereka selesaikan. Misalnya pada pertemuan pertama, 
peserta didik diajarkan mengenai konsep elastisitas yaitu fenomena dimana seorang atlet pelompat galah menarik tongkatnya dan tongkat tersebut melengkung namun setelah dilepaskan tongkat tersebut dapat lurus seperti semula. Pada saat menyelesaikan permasalahan tersebut peserta didik secara tidak langsung dilatih untuk dapat memilih penyebab-penyebab terjadinya fenomena tersebut secara berkelompok sehingga seluruh peserta didik aktif dalam berdiskusi sedangkan kelas kontrol disajikan fenomena fisika dalam bentuk contoh soal dan peserta didik yang aktif pada kelas kontrol hanya peserta didik yang memiliki kemampuan awal tinggi. Ditinjau dari nilai rata-rata, skor perindikator, nilai tertinggi dan nilai terendah bahwa kelas ekperimen menunjukkan nilai yang lebih tinggi dibandingkan dengan kelas kontrol.

Nilai rata-rata pemahaman konsep per indikator untuk peserta didik kelas eksperimen lebih tinggi dibandingkan dengan kelas kontrol kecuali pada indikator menjelaskan. Indikator menjelaskan berkaitan dengan kemampuan peserta didik untuk dapat menggunakan model sebab akibat dalam sebuah sistem. Proses pembelajaran yang diterapkan pada kelas eksperimen seharusnya mampu melatih kemampuan menjelaskan peserta didik karena peserta didik diberikan permasalahan fisika yang membutuhkan penafsiran untuk dapat menjelaskan mengapa permasalahan tersebut dapat terjadi sehingga dapat dijadikan hipotesis awal sesuai dengan penafsiran masing-masing peserta didik. Namun kenyataannya tidak sesuai dengan apa yang diharapkan yaitu kemampuan menjelaskan peserta didik kelas eksperimen kurang terasah. Hal ini dapat disebabkan karena beberapa faktor yaitu kemampuan peneliti dalam mengorganisasikan kelas yang masih kurang sehingga beberapa peserta didik tidak mengikuti proses pembelajaran dengan serius terutama saat kegiatan menganalisis dilakukan. Kegiatan menganalisis dilakukan secara berkelompok setelah peserta didik merumuskan hipotesis awal bersama kelompoknya salah satunya pada saat menganalisis konstanta pegas seri dan paralel dimana sebagian peserta didik tidak fokus terhadap kegiatan yang dilakukan karena kekurangan peneliti untuk dapat mengkondisikan alat yang tidak cukup dengan jumlah kelompok yang dibentuk.

Menurut Putri (2017:104) kekurangan dari model perolehan konsep ini ialah peserta didik yang memiliki kemampuan pemahaman rendah akan kesulitan untuk mengikuti pembelajaran, karena peserta didik diarahkan untuk menyelesaikan masalah-masalah yang disajikan dan tingkat keberhasilan pembelajaran ditentukan oleh penyajian data yang disajikan guru. Berdasarkan pendapat yang dikemukakan Putri mengenai kekurangan model perolehan konsep ini sesuai dengan beberapa hasil yang diperoleh dalam penelitian ini diantaranya kurang terlatihnya kemampuan peserta didik pada salah satu indikator kemampuan pemecahan masalah yaitu pengidentifikasian dan indikator menjelaskan yang termasuk salah satu dari indikator pemahaman konsep. Hal tersebut dapat terjadi karena kekurangan peneliti dalam mengolah dan mengemas informasi yang disajikan terutama pada saat penyajian fenomena yang berkaitan dengan konsep rangkaian seri paralel. Hasil diskusi peserta didik menunjukkan peserta didik tidak mampu mengidentifikasi penyebab terjadinya fenomena yang juga berdampak pada kurangnya kemampuan peserta didik dalam menjelaskan alasan fenomena dapat terjadi sehingga pada kedua indikator tersebut peserta didik memperoleh nilai yang rendah.

Pemberian perlakuan berupa model pembelajaran perolehan konsep berbasis masalah pada kelas eksperimen dan model pengajaran konvensional pada kelas kontrol menyebabkan adanya perbedaan nilai pada kedua kelas sebelum dan sesudah diberikannya perlakuan. Kelas eksperimen mengalami peningkatan baik dari segi nilai tertinggi, nilai terendah, nilai rata-rata maupun nilai per indikator. Pengaruh dari permberian perlakuan yang berbeda pada kedua kelas dapat dibuktikan dengan melakukan uji hipotesis. Uji hipotesis yang digunakan adalah uji hipotesis MANOVA. Uji MANOVA digunakan untuk mengetahui ada atau tidaknya pengaruh model pembelajaran perolehan konsep berbasis masalah pada materi elastisitas dan hukum Hooke pada kelas eksperimen. Hasil uji MANOVA dengan IBM SPSS menunjukkan bahwa model pembelajaran perolehan konsep berbasis masalah memberikan pengaruh pada kelas eksperimen, karena diperoleh nilai signifikansi $<0,05$, sehingga $\mathrm{H}_{a}$ diterima dan $\mathrm{H}_{0}$ ditolak yang artinya terdapat pengaruh model pembelajaran perolehan konsep berbasis masalah terhadap kemampuan pemecahan masalah dan pemahman konsep fisika peserta didik. Berdasarkan hasil yang didapatkan, maka dapat dikatakan bahwa penelitian ini berhasil sesuai dengan tujuan yang diharapkan.

Model pembelajaran perolehan konsep bertujuan mengembangkan serta menguatkan pemahaman peserta didik dalam proses kegiatan mental untuk praktik dan berpikir sehingga peserta didik lebih aktif dan antusias dalam mengikuti pembelajaran (Huda et. al., 
2017). Pembelajaran berbasis masalah merupakan inovasi dalam pembelajaran karena dalam PBM kemampuan berpikir peserta didik betul-betul dioptimalisasikan melalui proses kerja kelompok atau tim yang sistematis, sehingga peserta didik dapat memberdayakan, mengasah, menguji, dan mengembangkan kemampuan berpikirnya secara berkesinambungan (Nurdyansyah dan Fahyuni, 2016: 82). Sedangkan pembelajaran konvensional atau model pembelajaran yang berpusat pada guru menjadikan peserta didik tidak banyak melakukan aktivitas dalam pembelajaran yang pada akhirnya sangat mempengaruhi semangat belajar peserta didik yang berdampak pada kurang tercapainya tujuan pembelajaran (Triono, 2015: 50).

\section{SIMPULAN DAN SARAN}

Terdapat pengaruh model pembelajaran perolehan konsep berbasis masalah terhadap kemampuan pemecahan masalah dan pemahaman konsep fisika peserta didik kelas XI MIA di MAN 1 Mataram. Pengaruh ini berupa tingkat kemampuan pemecahan masalah dan pemahaman konsep fisika peserta didik pada kelas eksperimen lebih tinggi dibandingkan dengan peserta didik pada kelas kontrol.

Hendaknya lebih memperhatikan karakteristik materi, peserta didik, alokasi waktu, dan faktor pendukung lainnya agar proses pembelajaran yang diterapkan dapat tercapai secara maksimal. Selain itu, sebelum menerapkan model perolehan konsep berbasis masalah ini perlu dilakukan persiapan agar pada saat proses pembelajaran dapat berjalan sesuai dengan tujuan pembelajaran yang hendak dicapai.

\section{UCAPAN TERIMA KASIH}

Terima kasih yang sebesar-besarnya penulis sampaikan kepada Bapak Drs. Sutrio, M.Si., selaku dosen pembimbing I dan Bapak Aris Doyan, M.Si., Ph.D., selaku dosen pembimbing II yang selalu sabar dan ikhlas dalam membimbing penulis hingga penulisan skripsi ini selesai dan terimakasih juga kepada Ibu Jannatin 'Ardhuha, S.Si., M.Sc., selaku dosen penguji yang telah memberikan saran dan masukan dalam penulisan skripsi ini.

\section{DAFTAR RUJUKAN}

Eggen, P., \& Kauchak, D. (2016). Strategi dan Model Pembelajaran Mengajarkan Konten dan Keterampilan Berpikir Edisi Keenam. Jakarta: PT Indeks.

Fadilah, S., \& Suyono, S. (2016). Meremediasi Miskonsepsi Siswa Berbasis Gaya Belajar Dimensi Pemahaman Pada
Konsep Ikatan Kimia Menggunakan Concept Attainment. Unesa Journal of Chemical Education (ISSN. 22529454). 5(9). 464-473.

Hastuti, P., Sahidu, C., \& Gunawan, G. (2016). Pengaruh Model PBL Berbantuan Media Virtual Terhadap Kemampuan Pemecahan Masalah Fisika. Jurnal Pendidikan Fisika dan Teknologi. 2(3).

Herayanti, L., \& Habibi, H. (2015). Model Pembelajaran Berbasis Masalah Berbantuan Simulasi Komputer untuk Meningkatkan Keterampilan Berpikir Kritis Calon Guru Fisika. Jurnal Pendidikan Fisika dan Teknologi. 1(1).

Huda, N., Sadiman, S., \& Daryanto, J. (2015). Penerapan Model Pembelajaran Concept Attainment Berbantuan Film Dokumenter Penjajahan Untuk Meningkatkan Pemahaman Konsep Perjuangan Pada Siswa Sekolah Dasar. Jurnal Didaktika Dwija Indria, 4(1).

Kariadinata, R., \& Abdurahman, M. (2015). Dasar-dasar Statistik Pendidikan. Bandung : Cv Pustaka Setia.

Legat, E. (2018). Pengaruh Penerapan Model Pembelajaran Concept Attainment Terhadap Hasil Belajar Fisika Siswa Kelas XI MIA. Jurnal Riset Fisika dan Edukasi Sains. 5(1).

Listiawati, W., Gunawan, G., Sutrio, S. (2015). Pengaruh Penerapan Model Pembelajaran Berbasis Masalah Berbantuan Simulasi Interaktif Terhadap Hasil Belajar Fisika Siswa Kelas VIII SMPN 1 Pujut Tahun Pelajaran 2013/2014. Jurnal Pendidikan Fisika dan Teknologi. 1(1).

Maulidi, R., Muhardjito, M., \& Zulaikha, S. (2014). Kemampuan Pemecahan Masalah Melalui Strategi Pembelajaran Thinking Aloud Pair Problem Solving Siswa Kelas X SMA. Jurnal Fisika Indonesia. 18(54).

Nurdyansyah, N., \& Fahyuni, E. (2016). Inovasi Model Pembelajaran. Sidoarjo:Nizamia Learning Center.

Putri, P. D. 2017. Model Pembelajaran Concept Attainment dalam Meningkatkan Pemahaman Konsep Matematika. Jurnal Pemikiran dan Penelitian Pendidikan. 15(1).

Rahmi, F., \& Harahap, B. (2013). Pengaruh Model Pembelajaran Pencapaian Konsep Dengan Menggunakan Peta Pikiran Sebagai Upaya Mengurangi Miskonsepsi Siswa. Jurnal Inovasi Pembelajajaran Fisika. 1(2). 
Riana, R., Kartinawati, K., \& Suhito,S. (2019). Meningkatkan Kemampuan Pemahaman Konsep dan Motivasi Belajar Siswa SMP Negeri 11 Semarang Melalui Model Group Investigation Berbantuan Colour Ball. Jurnal Prisma. 2(1).

Riduwan. (2018). Dasar-dasar Statistika. Bandung: Alfabeta.

Risdawati, R., Mustami, K., \& Hamansah, H. (2017). Pengaruh Model Pembelajaran Concept Attainment Terhadap Aktivitas Dan Hasil Belajar Biologi Siswa di Kelas XI IPA SMAN 11 Bulukumba. Jurnal Biotek. 5(2).

Rusnayati, H., \& Prima, E. C. (2011). Penerapan Model Pembelajaran Problem Based Learning dengan Pendekatan Inkuiri untuk Meningkatkan Keterampilan Proses Sains dan Penguasaan Konsep Elastisitas pada Siswa SMA. Prosiding Seminar Nasional Penelitian, Pendidikan dan Penerapan MIPA, Fakultas MIPA, Universitas Negeri Yogyakarta: 332.

Sahara, L. (2015). Penerapan Model Concept Teaching Pendekatan Concept Attainment Untuk Meningkatkan Pemahaman Konsep Ipa Fisika Siswa Kelas VIII Smp Negeri 5 Kendari Pada Materi Pokok Usaha Dan Energi. Jurnal Pendidikan Fisika dan Teknologi. 1(2).

Setyosari, P. (2013). Metode Penelitian Pendidikan dan Pengembangan. Jakarta: Prenada Media Group.

Sa'diyah, H., Indrawati, I., \& Handayani, R.D. (2015). Model Pembelajaran Concept Attainment Disertai Metode Demonstrasi Pada Pembelajaran IPAFISIKA di SMP. Jurnal Pembelajaran Fisika. 4(3). $224-229$.

Trihono, T. (2015). Upaya Meningkatkan Pemahaman Konsep Fisika dan Kemampuan Kerja Kelompok melalui Penerapan Konstruktivisme pada Siswa Kelas VIII C SMP Negeri 1 Playen Tahun Pelajaran 2014/2015. Jurnal Riset dan Kajian Pendidikan Fisika UAD. 2(2). 